\title{
ANALYSIS OF AGRICULTURAL GROWTH USING LQ AND SHIFTSHARE METHODS \\ (Case Study : Manokwari Regency, Indonesia)
}

\author{
Prima Jiwa Osly ${ }^{1}$, Irfan Ihsani $^{1}$, Rhonny Einsten Ririhena ${ }^{2}$, Fulki Dwiyandi ${ }^{3}$, Ardini Putri $^{1}$ \\ ${ }^{1}$ Civil Engineering Department, Pancasila University \\ ${ }^{2}$ Agrotechnology Department, Pattimura University \\ ${ }^{3}$ Post Graduated School, Bogor Agricultural University \\ E-mail : primajiwa.osly@univpancasila.ac.id \\ Received $31^{\text {th }}$ March 2020 , Accepted $13^{\text {th }}$ April 2020
}

\begin{abstract}
Economic growth is an indicator of a process of economic development conducted both at the national and regional level. to increase economic growth that implemented through the effectiveness and efficiency of economic development, implementation of economic development needs to directed to the sectors that can give large multiplier effect on different sectors and the economy. Indonesia's economic development is closely related to agricultural development since Indonesia itself is an agrarian country that has most of its people as farmers. This research aims to find potential in the province of West Papua with selections of excellent commodities suitable to be developed and analyze sub-sector agriculture to the district economy Manokwari period 2013-2017 contributes. The method of analysis used is "Location Quotient" and Shift Share Analysis technique. The results showed that most of Manokwari district in West Papua Province has a base sector that is agriculture sector, services sector and building sector.
\end{abstract}

Keywords : agricultural sector, location quotient, shift share analysis 


\section{INTRODUCTION}

After enactment of Law No. 22 of 1999 about Regional Government, the regional autonomy system replaces the centralist system. With these conditions, each region has more freedom to decide which sector/commodity development prioritized. local government ability to see which sectors have advantages and disadvantages in its region becomes increasingly important. Sectors that have advantages will have better prospects to develop and expected to push other sectors to develop.

Course of economic development led to various changes, especially in economic structure. Changes in economic structure is one of characteristic occurred in economic growth on almost every developed country. Based on historical records, the sectoral growth rate is a form of slow shift and change from agricultural activities to non-agricultural activities and lately from industry sectors to service sectors. Regional development as an integral part of national development is a process to a planned shift to achieve the target and to improve citizens prosperity which includes involving available activities via citizens support in several sectors. Regional development must be appropriate with the condition, potency, and aspiration of the people who grow and develop. If the implementation of prioritized region development is not quite the potential of each region, then the utilization of available resources becomes less than optimal. The situation causes concerned region economy growth slows down. (Tustiana, 2016)

Indonesia's economic development is closely related to agricultural development, considering Indonesia is still an agrarian country where most people are farmers. Agricultural development with a sustainable development approach is a social ratio choice that needs to be developed, in line with economic developments and climate change that occur in the world and trade in era globalization which demands business efficiency and effectiveness. (Mulyono, 2106). The growth of an area's agricultural sector is influenced by its own competitive advantage, regional specialization and agricultural potential possessed by the region. The existence of agricultural potential in an area has no meaning for the growth of agriculture in that area if there is no effort to utilize and develop agricultural potential optimally. Therefore, the use and development of all potential agricultural potential must be a top priority to be explored and developed in implementing the full regional agricultural development. (Wicaksono, 2015)

\section{METHODS}

Case study of this research in West Papua Province Manokwari Regency, the overall area of Manokwari Regency is $1,556.94 \mathrm{~km} 2$ with consideration of the potential that exists in the region known as an area rich in natural resources but faces severe development challenges in improving the investment climate, improving service quality and strengthening the government. Geographical isolation and limited access to quality knowledge become its challenges.

\section{Location Quotient (LQ) Analysis}

This research is using Location Quotient (LQ) Analysis to determinate superior commodity. This technique is comparing how significant the role of those sector in one area for the role in national level. This technique is used to identify internal potential the area has which is basic sector and to be non-basic sector (Rasyi, 2016). $\mathrm{LQ}$ is measure the ratio between local and national share from the productive activity of certain industry in a region, usually using the man power as a representative of those production activity. LQ bigger than 1 can be interpreted as the investigated industry is more concentrated on its region than national average. Some researcher using LQ rate above 1,25 or 2 to limit industry alogromation in a region (Tian, 2013). LQ analysis is used to determinate commodity of agriculture sub sector which has comparative advantages, with the criteria LQ $>1$. Mathematically, LQ formula written as: (Čadil, Petkovová, \& Baltná, 2014):

$$
\mathrm{LQ}=\frac{\frac{E \boldsymbol{i} j}{E \boldsymbol{i}}}{\frac{E \boldsymbol{j}}{E}}
$$

Operationally, that $L Q$ formula is written as:

$$
L Q=\frac{p i / p t}{P i / P t}
$$

Whereas:

$\mathrm{pi}=$ areal wide of commodity "i" harvesting at regional level

$\mathrm{pt}=$ areal wide of sub sector commodity "i" harvesting at regional level

$\mathrm{Pi}=$ areal wide of commodity "i" harvesting at national level

$\mathrm{Pt}=$ areal wide of sub sector commodity "i" harvesting at national level

Result of LQ calculation produce 3 criteria, which as: (Hendryana, 2016)

LQ>1 has meaning of the commodity being basic or being the growth source. The commodity has comparative advantages; the result is not only can meet the demand in the concerned region, but also can be exported to the outside of region. Commodity that produce LQ rate $>1$ is being a normative standard to set as superior commodity. If there are many commodities that produce LQ rate $>1$ but only one needed, the chosen commodity must have the highest $L Q$ rate. Because the higher $L Q$ rate in a region, is related to higher the potential of superior commodity.

$\mathrm{LQ}=1$ has meaning of that commodity is non-basic, has no comparative advantages. The production is only enough to meet the demand of the region itself and unable to exported.

$\mathrm{LQ}<1$ has meaning of that commodity is also non basic. The commodity production in a region cannot 
meet the demand of the regional itself so need to be supplied or imported.

\section{Shift Share Analysis}

Shift share analysis has been used to describing regional and industry economic growth by rating for the structural effect and regional or industry competitiveness and emphasize on changing through times. (Shi \& Yang, 2008). Most of regional growth and employment growth are using aggregate variable information to describe the growth of Gross Domestic Income sources or work at certain region, so the main purpose of Shift Share Analysis for regional growth analysis is to outline the growth of Gross Domestic Income and/or working chance so it able to describe competitiveness and region unique. Shift Share Analysis method also giving detail about unique of growth and local industry competitiveness (hasan, Rashid \& hamid, 2011).

Shift Share Analysis is used to determinate sub sector commodity of crops which has competitive advantages, by the SSA criteria is positive (Mulyon, et al, 2016). Classically, SSA dividing growth as changing (D) of some variable in province like Gross Regional Domestic Income, value-adding-value, income or output, for a certain time is being effects of: National growth (N), Proportional growth (M) and competitive advantages (C). The effect of national growth is called share effect, the effect of proportional growth is named proportional shift and competitive advantages effect is named differential shift or regional share (Abidin, 2015). Mathematically, SSA method is formulated as:

$$
\mathrm{Dij}=\mathrm{Nij}+\mathrm{Mij}+\mathrm{Cij}
$$

Rating criteria: (Abidin, 2015)

If $\mathrm{Mij}>0$, the growth of sector "i" is fast at province region

If $\mathrm{Mij}<0$, the growth of sector "i" is slow at province region

If $\mathrm{Cij}>0$, the sector/region "j" has good competitiveness rather than other sector /province of sector "i"

If $\mathrm{Cij}<0$, sector "i" at province region is unable to compete well compared to other region.

\section{RESEARCH AND DISCUSSION RESULTS}

\section{Location Quotient (LQ) Analysis}

Potential sector to be developed because the sector not only fulfill the needs within the region but also meet in other areas. Location Quotient (LQ) calculation of the Manokwari District is taken from the period 20142017. From the calculation of the LQ index of the Manokwari District during the 3-year observation period, the basis and non-basis sectors can be identified. The value of $L Q>1$ means that the role of $a$ sector in the district is more dominant than the provincial sector and as a guideline that the district will be surplus to the product of the sector. If the $L Q<1$ means the role of the sector is smaller in the district than its role at the provincial level.

The following will be stated the calculation of LQ for the Manokwari district from 2013 until 2017. LQ is calculated against West Papua Province as its parent region. This analysis used the PDRB data at a constant price of 2000 . Here are the calculation results of LQ Manokwari

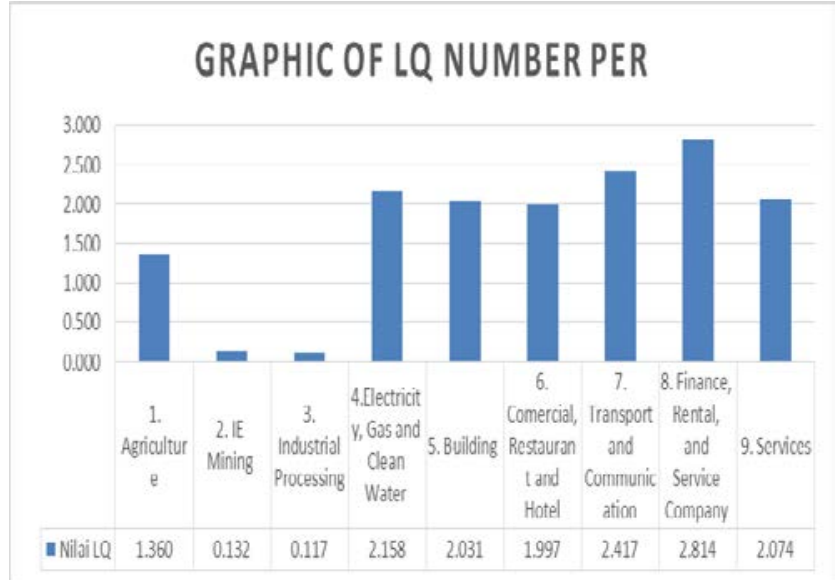

Figure 1. Graphic of total LQ number by Business Field/sector from 2013 - 2017 in Manokwari

From the table above the development of annual LQ from 2014 - 2017 by Business Sector in Manokwari District seven sectors have $\mathrm{LQ}>1$ and only two sectors that have $\mathrm{LQ}<1$. The highest sector that has $\mathrm{LQ}>1$ is Finance, Rental, and Service Company Sector (no. 8) with 2,814 and the Agriculture Sector (no. 1) comes as the lowest with 1,360. The two sectors that have the $\mathrm{LQ}<1$ is the Mining and Excavation Sector (no. 2) with 0,132 and Industrial Processing Sector (no. 3) with 0,117.

From the LQ calculation results in table 1 , there are two groups, namely $L Q>1$ and $L Q<1$ which can be described as follows :

1. The results of the $L Q$ calculation above that the business field/sector has the LQ $>1$ :

The Agriculture Sector is one of the basic sectors or a source of regional economic activator and increase in community revenue due to $L Q>1$, however, Agriculture Sector is not a major source of supporting the regional economy, because the Agriculture Sector $\mathrm{LQ}>1$ for 1,360 compared to the Finance, Rental and Services Companies Sector that has $\mathrm{LQ}>1$ for 2,814, Transport and Communication Sector $\mathrm{LQ}>1$ for 2,417; Electricity, Gas and Clean Water Sector LQ > 1 for 2,158; Services Sector $\mathrm{LQ}>$ value for 2,074; Building Sector $\mathrm{LQ}>1$ value for 2,031; and Comercial, Restaurant and Hotel Sector value of LQ $>1$ for 1,997 .

2. From the results of the calculation $L Q$ above that the business field/sector that owns the LQ $<1$ IE Mining sector of 0.132 and excavation and 
processing industry sector of 0117 means the role of both sectors are not a superior and less potential to be developed as a regional economic mobilizer.

To know the prediction of the superior sector of regional economic support for the next 20 years 2017 2037 using SPSS Statistic. Can be seen in Figure 2.

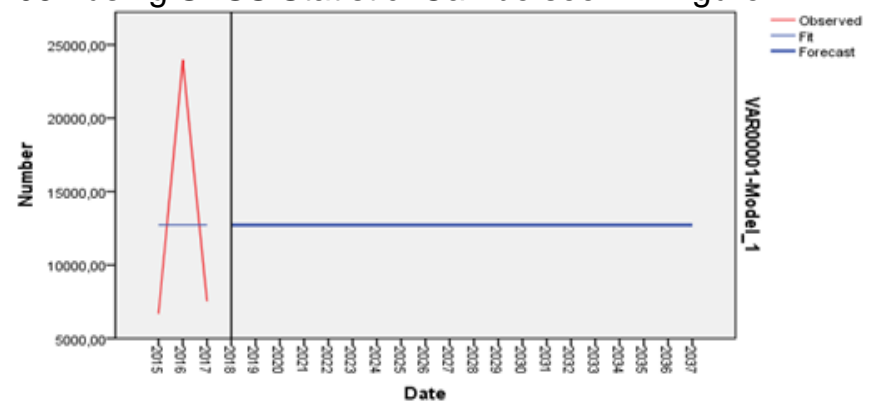

Figure 2. Development LQ Agriculture District by Business Field/sector from 2017 - 2037 in Manokwari

The chart above explained that the agriculture sector is decreasing as the flagship sector supporting the regional economy in Manokwari District in the 20 years to come.

\section{SHIFT SHARE ANALYSIS}

Analysis of Shift Share is used to determine the economic growth process of the Manokwari district is associated with the regional economy. The analysis of Shift Share in this study used the revenue variable, namely PDRB to describe the economic growth of the Manokwari district. The change (growth) of the specific sector in the PDRB Manokwari District is a summation of the Provincial Share or national growth (NIJ), Proportional Shift or Industrial Mix (MIJ), and Differential Shift or excellence Competitive (CIJ).

1. The level of excellence of the competitive sector

Differential shift components are used to determine the competitive advantage of a sector. Calculation results show a competitive ability indicator. Commodity values with differential shift results of $>0$ are positive and the sector value with differential shift $<0$ is a negative sector. Based on the analysis results $\mathrm{Cij}$ (differential Shift) showed: Agriculture Sector has a level of competition with a competitiveness of 12723,564 to be developed in West Papua but not as a major factor for the source of regional economic activator and increase in public income such as the Services Sector with a competitiveness of 14557,354 the Mining Sector with 7508.90, the Industrial Processing Sector with 2764.74, the Electricity, Gas and Clean Water Sector with 263.25 and lastly Rental and Services Company Sector with amounted to 134.02. These sectors also have a competitiveness level $(\mathrm{Cij}>0)$. The Agricultural Sector is higher in competitiveness than the Building Sector which has a $\mathrm{Cij}<0$ with 6342.75, the Transportation Sector with 6189.12 and The
Communications with 6189.19 but the Building, Transport, and Communication Sector is still included in the basic sector because it has an LQ level value, growth, and progression more than $0(<0)$. It can be concluded that the Agriculture Sector has one of the good competitiveness in West Papua Province

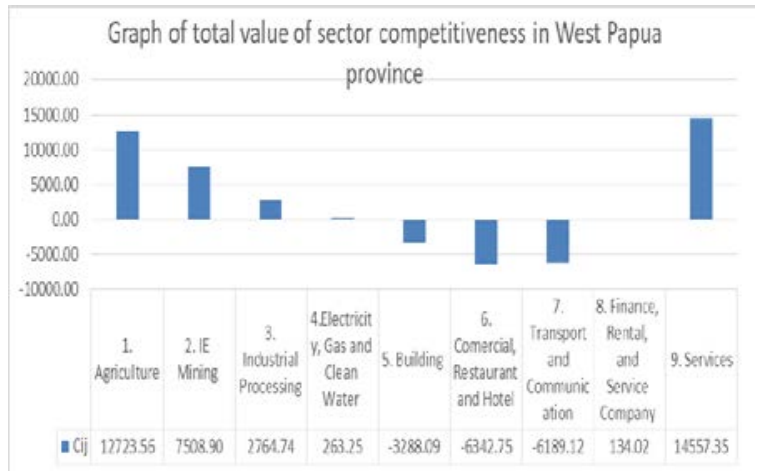

Figure 3. total value of sector competitiveness graph in west papua province from $2013-2017$

To find out the forecast of the agricultural sector's competitive advantage for 20 years to come in 2017 2037 using SPSS Statistics. Can be seen in Figure 4.

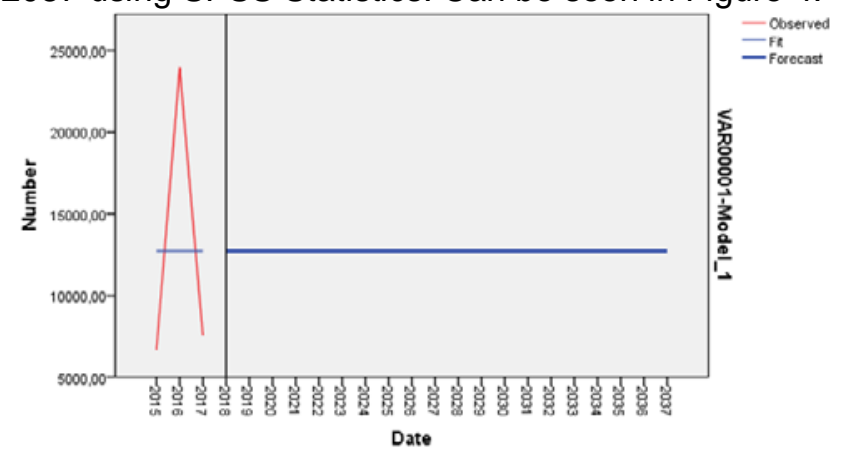

Figure 4. Graph of total competitiveness of agricultural sector in West Papua province From 2017 - 2037

From the picture above, the level of excellence chart indicates that the agricultural sector is experiencing stability annually as a supporting regional economy in West Papua Province in 20 years to come.

\section{Growth Rate}

With proportional growth is the value of Mij (growth rate) $>0$. The growth rate of development:

- The agriculture sector experienced a growth rate of $<0$, namely-7534,332; Mining and Excavation Sector with 6713,774; the Industrial Property Sector with $3,118,490$ and the Electricity, Gas, and Clean Water Sector with 45,768 . The following sectors are subject to have negative growth rate sectors caused by several factors.

- And vice versa for the Building Sector at a growth rate that has an increased growth stack of 76435,468 , the Comercial, Restaurant, and Hotel Sector with 26713,502, the Transport 
and Communications Sectors of 26335,944, the Finance, Rental and Company Services Sector with 9370.39 and the Services Sector of 44787,950 which has a positive growth. Thus, the Agricultural Sector was declining in the growth rate and still based on the source of regional economic activator to increase the income of Manokwari District community

It can be concluded that the agricultural sector is experiencing a decline in the growth rate is estimated due to the continued shrinking agricultural land in the allocation of buildings because the Building Sector has the highest growth.

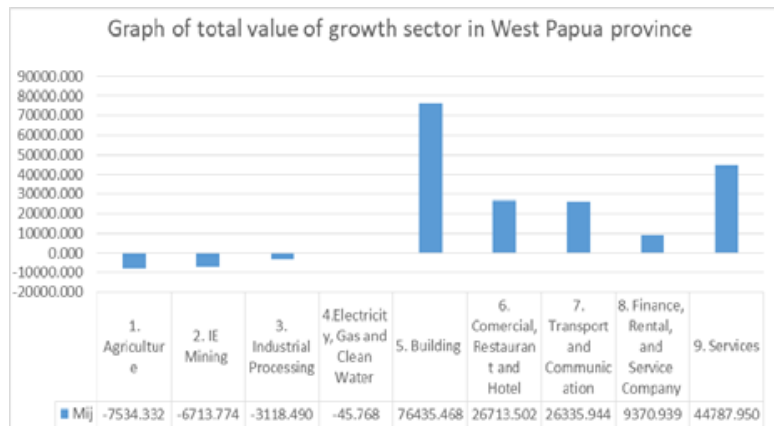

Figure 5. Graph of total growth value sector in West Papua province from 2013 - 2017

To find out the predicted growth rate of the sector for 20 years to come in the years 2017- 2037 using SPSS Statistics. Can be seen in Figure 6.

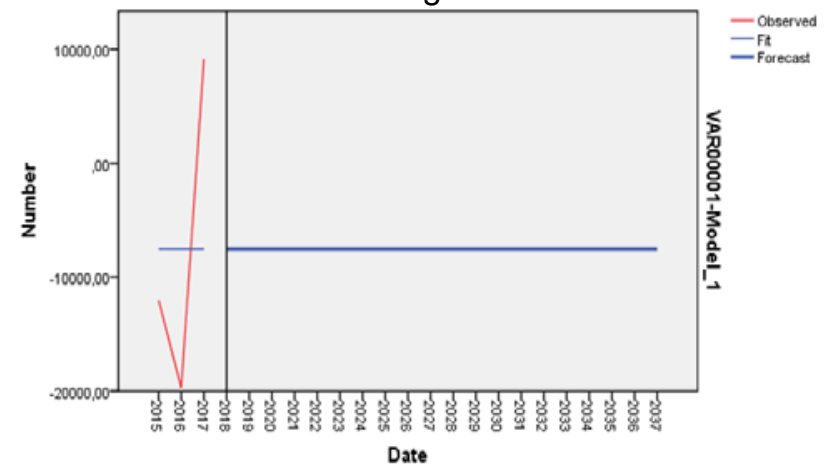

Figure 6. Chart of total value of agricultural sector growth in West Papua province from year 2017 - 2037

From the picture above the growth, the graph shows that the agricultural sector is experiencing stability every year, supporting the local economy in West Papua Province in 20 years to come.

\section{Progression level}

The results of the analysis showed all sectors of the value of progression (DIJ) $>0$ which is the Agricultural Sector has a progression level rate of 39790,966, however, the Agricultural Sector is not a major support for the regional economy in West Papua province, the Mining and Excavation sector with 7743,958, the Industrial Processing Sector with 8578,764, the Electricity, Gas and Clean Water Sector with 1,222,958, the Buildings Sector with 132733.61,
Comercial, Restaurants, and Hotels with the amount of 494689,61, the Transport and Communications Sectors with 48,114,497, the Finance, Rental and Company Services Sector with 27,616,266, and the Services Sector with 120696.70. So that it can be concluded that all sectors are positive including the progressive (advanced) spread in West Papua province.

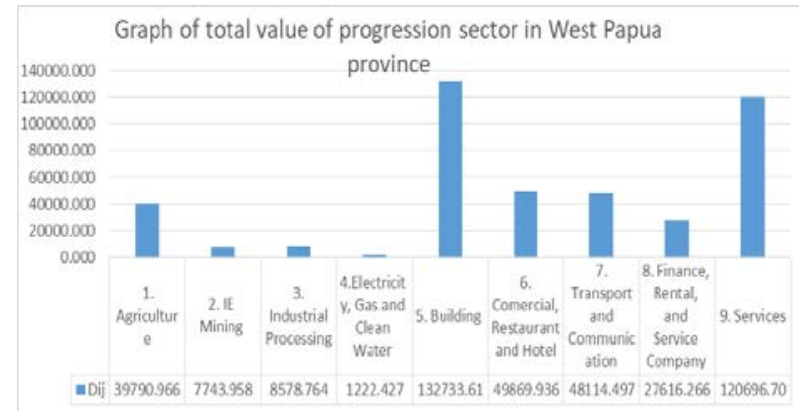

Figure 7. Graph of total level of progesivitas sector of each district in West Papua province from 2013 - 2017

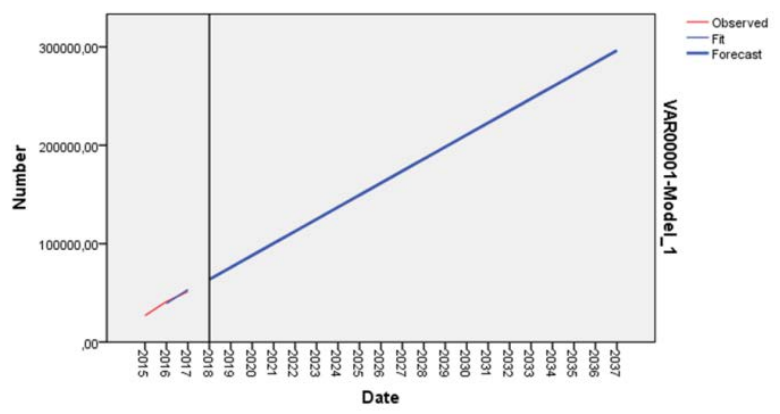

Figure 8. Graph of total value of the level of progesivity of agricultural sector in West Papua province from year $2017-2037$

From the picture above graph level progression shows that the agriculture sector against LQ has decreased by progression very tired every year.

\section{CONCLUSION}

Based on the results of the Location Quotient (LQ) and Shift Share Analysis is known that the economic sectors in the Manokwari district of West Papua Province have different competitive and comparative advantages. From the 3 components, it has a basis sector such as the Agriculture Sector, the Services Sector, and the Buildings Sector.

A decrease in the Agricultural Sector for the component value growth is caused by agricultural land and agricultural productivity that continues to shrink. Therefore, it is constantly feared will interrupted food endurance, so it requires imports to fulfill it. The impact of agricultural land conversion on the economic value is reduced in food production.

With increasingly shrinking agricultural land in the decline of $L Q$ value due to land function. Land is a major factor in agricultural development. At UU No. $41 / 2009$ on Lahan Pertanian Pangan Berkelanjutan (LP2B), it can withstand the conversion rate of rice 
paddy fields, especially rice fields with technical irrigation to support the national food endurance and Indonesia has a lasting agricultural land.

\section{REFERENCES}

Abidin, Z. (2015). Aplikasi Analisis Shift Share Pada Transformasi Sektor Pertanian Dalam Perekonomian Wilayah Di Sulawesi Tenggara . Informatika Pertanian, Vol. 24 No.2, 166-167.

Endrayana, R. (2016, March 31). Aplikasi Metode Location Quotient (LQ) dalam Penentuan Komoditas Unggulan Nasional. Retrieved February 5, 2018, from ResearchGate: www.researchgate.net/publiction/267919017

Faisal. (2015). Economic Growth Analysis of Six Divisions of Bangladesh Using Location Quotient and Shift-Share Method. Journal of Bangladesh Institute of Planners, Vol. 8, 2015

Hendrayana, R. (2016, March 31). Aplikasi Metode Location Quotient (LQ) dalam Penentuan Komoditas Unggulan Nasional. Retrieved February 5, 2018, from ResearchGate: www.researchgate.net/publiction/267919017
Kusaini, Moh. (2015) A Shift-share analysis on regional competitiveness a case of Bayuwangi district, East Java, Indonesia. Malang. Brawijaya University

Mulyono, J., \& Munibah, K. (2016, Desember 2). Pendekatan Location Quotient Dan Shift Share Analysis Dalam Penentuan Komoditas Unggulan Tanaman Pangan Di Kabupaten Bantul. Informatika Pertanian.

Tustiana, L, Puspita. (2016) Analisis Perbandingan Faktor-Faktor Penyebab Ketimpangan Pembangunan Antar Kabupaten/Kota Di Kawasan Kedung sapur. Semarang. ekonomi pembangunan

Wicaksono, Agus. (2015) Analisis Location Quotient Sektor dan Subsektor Pertanian pada Kecamatan di Kabupaten Purworejo. Universitas Muhammadiyah Purworejo. 